\title{
The Death of Class Arbitration After Concepcion?
}

\author{
Maureen A. Weston*
}

\section{INTRODUCTION}

Is the "death knell" of class arbitration found in the fine print? In AT\&T Mobility LLC $v$. Concepcion, the Supreme Court potentially allowed for the evisceration of class arbitration, and indeed most class actions, in consumer and employment settings where contracts contain a pre-dispute arbitration provision that only authorizes claims brought in an individual capacity or that expressly bans representative class actions in arbitration or court ("class action waivers"). ${ }^{1}$

The Court indirectly addressed the issue of class arbitration in prior cases where it had seemed to validate the concept of arbitral class actions. Southland $v$. Keating, for example, held that the Federal Arbitration Act (FAA) preempted a state law that required judicial recourse for franchise claims, although the Court acknowledged that

\footnotetext{
* Associate Dean for Research/Professor of Law, Pepperdine University School of Law. The author would like to thank the University of Kansas Law Review and participants at the Symposium on Perspectives on the Current State of Arbitration Law held in Lawrence, Kansas in November, 2011.

1. 131 S. Ct. 1740, 1746-48 (2011). But see Sutherland v. Ernst \& Young LLP, No. 10 Civ. 3332(KMW)(MHD), 2012 WL 130420, at *4-5 (S.D.N.Y. Jan. 17, 2012) (declining to apply Concepcion to an employment dispute where the plaintiff has no alternative, other than collective action, to vindicate her rights); In re D.R. Horton, Inc., 357 N.L.R.B. No. 184, at *11-12 (Jan. 3, 2012) (distinguishing Concepcion in a case involving an agreement between employers and employees). The term "class action waiver" is also used to describe contractual provisions that require individual arbitration and that prohibit representative actions whether in a judicial proceeding or arbitration. Shroyer v. New Cingular Wireless Servs., Inc., 498 F.3d 976, 980 (9th Cir. 2007) (quoting language from Cingular's contract prohibiting any form of class proceeding). Some might object that the term "waiver," defined as an intentional relinquishment of a known right, is euphemistically applied, but the term "class action waiver" has taken hold and is commonly used. See, e.g., Olmstead v. Dell, Inc., 533 F. Supp. 2d 1012, 1015-18 (N.D. Cal. 2008) (using the term "class action waiver" throughout the opinion to refer to a similar provision). Not only do these contracts require individual arbitration, relieving one of the right to go to court, many arbitration provisions now contain a class arbitration waiver that bars individuals from bringing representative claims in court or arbitration at all. See, e.g., Concepcion, 131 S. Ct. at 1744 (providing for both binding arbitration of any claim as well as requiring claims be brought individually); Shroyer, 498 F.3d at 980 (same); Olmstead, 533 F. Supp. 2d at 1014 (same).
} 
these claims could be resolved in a class arbitration procedure. ${ }^{2}$ In Green Tree Financial Corp. v. Bazzle, a plurality of the Court held that where a pre-dispute arbitration contract was silent on the issue of class actions, the arbitrator is to decide whether the parties intended to bar or permit the filing of class claims in arbitration or court. ${ }^{3}$ In response to Bazzle, arbitration providers such as the American Arbitration Association and JAMS promulgated comprehensive rules addressing the procedures for class arbitration ${ }^{4}$ and have since administered hundreds of class arbitrations.

Recent arbitration cases before the Roberts Court, however, take a decidedly more critical view of class arbitration, while maintaining a favorable, if not romantic, view of bilateral arbitration. ${ }^{5}$ In Stolt-Nielsen S.A. v. AnimalFeeds International Corp., the underlying arbitration agreement was silent on the issue of class arbitration. ${ }^{6}$ On the basis that the agreement did not preclude class arbitration, the arbitration panel ordered class arbitration. ${ }^{7}$ Ruling that in so doing the panel exceeded their authority or acted in manifest disregard of the law, the Court held that a party may not be compelled under the FAA to submit to class arbitration unless there is a contractual basis for concluding that the parties agreed to class arbitration. ${ }^{8}$ The Court expressed a strong distaste for class arbitrations and described at length the presumed differences between bilateral and class arbitrations. ${ }^{9}$ Stolt-Nielsen portended the

2. 465 U.S. 1, 10, 17 (1984); see also Maureen A. Weston, Universes Colliding: The Constitutional Implications of Arbitral Class Actions, 47 WM. \& MARY L. REV. 1711, 1733 n.77 (2006) ("The Court did not discuss class arbitration ... yet it implicitly acknowledged that class actions could be brought in arbitration.” (discussing Southland)).

3. 539 U.S. 444, 452-53 (2003) (plurality opinion).

4. See Am. Arbitration Ass'n, Supplementary Rules for Class Arbitrations (2003), available at http://www.adr.org (search "Supplementary Rules for Class Arbitration"; then follow "Supplementary Rules for Class Arbitration” hyperlink); see also AM. ARBITRATION Ass'N, AAA POLICY ON ClASS ARBITRATIONS (2005), available at http://www.adr.org (search "AAA Policy on Class Arbitrations") (describing AAA policy to seek court guidance prior to enforcing contracts which expressly ban class actions); JAMS, JAMS ClASS ACTION PROCEDURES R. 1(a) (2009), available at http://www.jamsadr.com/rules-class-action-procedures ("JAMS will not administer a demand for class action arbitration when the underlying agreement contains a class preclusion clause, or its equivalent, unless a court orders the matter or claim to arbitration as a class action.”).

5. Jeffrey Stempel, Tainted Love: An Increasingly Odd Arbitral Infatuation in Derogation of Sound and Consistent Jurisprudence, 60 U. KAN. L. REV. 795 (2012).

6. 130 S. Ct. 1758,1766 (2010).

7. Id. at 1766 .

8. Id. at 1776. Although the parties had signed a submission agreement giving the arbitration panel authority to decide the class arbitration issue, the Court opted to rule on this issue. Id. at 1779-80 (Ginsburg, J., dissenting).

9. Id. at $1775-76$ (majority opinion). 
demise of class arbitration in holding that parties to an arbitration contract cannot be compelled to class-wide arbitration absent agreement to that process. ${ }^{10}$ Since silence appeared to provide an escape from class arbitration under Stolt-Nielsen, express bans on class actions or arbitration only seemed to run the risk of being struck down under state law as unconscionable or contrary to public policy. But as Stolt-Nielsen did not foreclose class arbitration, what of contractual provisions that ban class relief altogether?

The debate over the enforceability of class action waivers, which had been percolating for years in both state and federal courts, came to the forefront in Concepcion when the Court agreed to review application of the California Supreme Court's ruling in Discover Bank v. Superior Court, which deemed some class action waivers in adhesion contracts unconscionable, exculpatory, and thus illegal under California law. ${ }^{11}$ "The 'principal purpose' of the FAA is to 'ensur[e] that private arbitration agreements are enforced according to their terms.",12 But section 2 provides for the judicial enforcement of agreements to arbitrate, "save upon such grounds as exist at law or in equity for the revocation of any contract." 13 This "savings clause" has long been interpreted as holding arbitration contracts to the standards of generally applicable state contract law, including defenses applicable to any contract, such as fraud, duress, unconscionability, or public policy. ${ }^{14}$ Under Discover Bank, many consumer contract class waivers would be struck down as unconscionable, and the case would proceed in class arbitration. ${ }^{15}$

In a 5-4 decision, the Concepcion Court stated that California's judicial rule invalidating class action waivers as unconscionable "stands as an obstacle to the accomplishment and execution of the full purposes and objectives of Congress [in the FAA]." "Therefore, according to the Court, the FAA preempted the California law. ${ }^{17}$ Writing for the

10. Id. at 1776 .

11. 131 S. Ct. 1740, 1745 (2011) (citing Discover Bank v. Superior Court, 113 P.3d 1100, 1108-09 (Cal. 2005), abrogated by Concepcion, 131 S. Ct. 1740).

12. Id. at 1748 (quoting Volt Info. Scis., Inc. v. Bd. of Trs. of Leland Stanford Junior Univ., 489 U.S. 468, 478 (1989)).

13. 9 U.S.C. § 2 (2006) (emphasis added).

14. See Prima Paint Corp. v. Flood \& Conklin Mfg. Co., 388 U.S. 395, 404 n.12 (1967) (“As the 'saving[s] clause' in $\S 2$ indicates, the purpose of Congress in 1925 was to make arbitration agreements as enforceable as other contracts, but not more so.”).

15. 113 P.3d at 1110.

16. 131 S. Ct. at 1753 (quoting Hines v. Davidowitz, 312 U.S. 52, 67 (1941)) (internal quotation marks omitted).

17. Id. 
majority, Justice Scalia described bilateral arbitration as streamlined, efficient, and cheap. ${ }^{18}$ He characterized class arbitration, by contrast, as "slower, more costly, and more likely to generate procedural morass."19 The majority further asserted that class arbitration, with no effective means of judicial review, imposes higher risks on defendants who are unlikely to "bet the company" on such a process. ${ }^{20}$ Even if class proceedings are needed to vindicate small-dollar claims that might otherwise go unredressed, according to the Court, the "States cannot require a procedure that is inconsistent with the FAA." 21

In light of Concepcion, a number of state and federal courts have enforced class action waivers in consumer arbitration contracts over objections that the waivers effectively immunize defendants from liability or violate state law standards of unconscionability or public policy. $^{22}$ Considered a "get out of class actions free" card, Concepcion has provided the impetus for the business community to include express class waivers in their contracts. ${ }^{23}$ Class actions, which permit one or more parties to assert claims on behalf of similarly situated individuals, have been part of the U.S. legal landscape since 1966 when Congress promulgated Rule 23 of the Federal Rules of Civil Procedure to provide for class actions. ${ }^{24}$ Class actions are admittedly controversial, viewed by some businesses as "legalized blackmail,"25 yet also regarded as serving an important public function allowing "those who are less powerful to band together-using lawyers as their champions"-to seek redress of grievances that would "go unremedied if each litigant had to fight

18. Id. at 1749. Justice Scalia did not provide empirical data to support his description of bilateral arbitration. See id. This view of arbitration is at odds with reports from users of the commercial arbitration process. See Thomas J. Stipanowich, Arbitration: The "New Litigation," 2010 U. ILL. L. REV. 1, 8 (noting that "[b]y the beginning of the twenty-first century . . it was common to speak of U.S. business arbitration [as] . . formal, costly, time-consuming, and subject to hardball advocacy").

19. Concepcion, 131 S. Ct. at 1751.

20. Id. at 1752 .

21. Id. at 1753 .

22. See, e.g., Meyer v. T-Mobile USA Inc., No. C 10-05858 CRB, 2011 WL 4434810, at *9 (N.D. Cal. Sept. 23, 2011) (citing Concepcion in enforcing an arbitration clause over the public policy objections of the plaintiff).

23. Jean R. Sternlight, Tsunami: AT\&T Mobility LLC v. Concepcion Impedes Access to Justice, 90 OR. L. REV. 703, 708 (2012) (noting that courts are upholding arbitral class action waivers in a variety of contexts).

24. See Ortiz v. Fibreboard Corp., 527 U.S. 815, 832-33 (1999) (noting the historical basis for representative suits emerged from early English law and explaining its modern emergence in Rule 23); Owen M. Fiss, The Political Theory of the Class Action, 53 WASH. \& LEE L. REV. 21, 25 (1996) (asserting the public purposes served by private citizen class actions).

25. Weston, supra note 2, at 1726 (gathering cases). 
alone. ${ }^{26}$ Class arbitration takes these representative actions before a private tribunal. ${ }^{27}$ Could it be that, under Concepcion, judicial and arbitral class actions could be eliminated though a mere strike of a pen? ${ }^{28}$

This Article examines the implications of Concepcion on the future of class actions, in court or arbitration, and analyzes the federalism issues at stake in the Court's interpretation of FAA preemption of state law. Part II of this Article sets forth the regulatory framework governing arbitration under the FAA and key Supreme Court decisions involving questions of class arbitration prior to Concepcion. Part III analyzes Concepcion and the decision's scope and parameters. Part IV contemplates Concepcion's impact, examining how federal and state courts have since interpreted Concepcion's application to challenges to class action waivers in cases involving statutory claims at the state and federal level. Part V introduces potential legislative responses and argues that the Concepcion decision, based on a dated and deluded conception of arbitration, improperly guts the FAA savings clause, violates the reserved role of states under the FAA to "regulate contracts, including arbitration clauses, under general contract law principles,"29 and threatens the ability of parties in some cases to vindicate their statutory rights. The Article concludes by advocating for a narrow construction of the decision and the guarantee of a procedural option by which rights, which sometimes require collective action, can be meaningfully vindicated.

\section{Federal Arbitration LAW, Policy, AND Scope}

\section{A. Federal Policy Favoring Arbitration}

The regulatory framework for arbitration in the United States is set forth in the Federal Arbitration Act of $1925 .^{30}$ Under section 2 of the

26. Id. at 1714 \& n.2 (quoting Robert H. KlONOFF \& EDWARD K.M. BILICH, Class ACTIONS AND OTHER MULTI-PARTY LITIGATION 6 (2000)) (internal quotation marks omitted).

27. Id. at 1735-36 (describing three approaches to administering class arbitration).

28. See Thomas J. Stipanowich, The Third Arbitration Trilogy: Stolt-Nielsen, Rent-A-Center, Concepcion and the Future of American Arbitration, 22 AM. REV. INT'L ARB. (forthcoming 2012) (noting that the Court has removed barriers aimed at consumer protection through its decision in Concepcion). But see Weston, supra note 2, at 1723 (dismissing the likelihood that class action waivers could be enforced, "[b]oldly assuming the strike of a pen ... cannot be used to eviscerate class action[s]").

29. Allied-Bruce Terminix Cos. v. Dobson, 513 U.S. 265, 281 (1995).

30. 9 U.S.C. $\S \S 1-16$ (2006). The FAA is a seemingly straightforward statute, comprised of sixteen sections, providing the procedural rules governing the enforcement of valid arbitration 
FAA, "[a] written provision in any maritime transaction or a contract evidencing a transaction involving commerce to settle by arbitration ... shall be valid, irrevocable, and enforceable, save upon such grounds as exist at law or in equity for the revocation of any contract." ${ }^{11}$ Because the Act invokes Congress's Commerce Power as its jurisdictional basis, the Supreme Court has ruled that the FAA applies in state and federal court and preempts conflicting state law. ${ }^{32}$ A fundamental principle underlying the FAA is to respect freedom of contract. While the FAA may be regarded as federal pro-arbitration policy, Congress, through the FAA's savings clause, retained a role for states to hold arbitration contracts to the standards of generally applicable state contract law, including defenses applicable to any contract, such as fraud, duress, unconscionability, or contrariness to public policy. ${ }^{33}$

Arbitration provisions became standard in employment contracts after the Court, in Gilmer v. Interstate/Johnson Lane Corp., upheld the enforcement of pre-dispute arbitration provisions of federal statutory claims, despite the employee's objections of process unfairness. ${ }^{34}$ Arbitration provisions in consumer adhesion contracts are even more ubiquitous. ${ }^{35}$ Although the Supreme Court has consistently upheld the

agreements. See generally Maureen A. Weston, Preserving the Federal Arbitration Act by Reining in Judicial Expansion and Mandatory Use, 8 NEV. L.J. 385, 390-93 (2007) (describing application of the FAA provisions).

31. 9 U.S.C. $\S 2$ (emphases added).

32. Southland Corp. v. Keating, 465 U.S. 1, 15 (1984). The proposition that the FAA is more than a procedural statute and applies in state courts has been the subject of much criticism, including that by Justices Scalia, Thomas, and O'Connor, because the express language of section 4 directs a U.S. district court to compel arbitration of a valid arbitration agreement. See, e.g., id. at 29 (O’Connor, J., dissenting) (citing 9 U.S.C. § 4). Yet, based on stare decisis, the FAA preemptive effect has been accepted and enforced in numerous arbitration cases. See, e.g., Allied-Bruce, 513 U.S. at 284 (O’Connor, J., dissenting).

33. Doctor's Assocs., Inc. v. Casarotto, 517 U.S. 681, 687 (1996); Allied-Bruce, 513 U.S. at 281. In acknowledging that section 2 permits states to apply general contract law defenses to invalidate arbitration clauses, the Court stated in Allied-Bruce:

States may regulate contracts, including arbitration clauses, under general contract law principles and they may invalidate an arbitration clause "upon such grounds as exist at law or in equity for the revocation of any contract." What States may not do is decide that a contract is fair enough to enforce all its basic terms (price, service, credit), but not fair enough to enforce its arbitration clause. The Act makes any such state policy unlawful ....

Id. (citing 9 U.S.C. $§ 2$ (emphasis added)).

34. 500 U.S. 20, 30-32 (1991) (responding to the plaintiff's attacks on the inadequacies and limited protections of the arbitration process as mere speculation).

35. Sarah Rudolph Cole, On Babies and Bathwater: The Arbitration Fairness Act and the Supreme Court's Recent Arbitration Jurisprudence, 48 Hous. L. REV. 457, 499-505 (2011) (citing various studies showing that businesses continue to expand their use of arbitration contracts in 
arbitrability of individual disputes involving federal or state statutory and common law claims and has regarded arbitration as simply "another forum," it has also cautioned that the ability to vindicate substantive rights must not be impaired. ${ }^{36}$

The FAA was enacted to reverse then long-standing judicial hostility to private agreements to arbitrate or to ouster courts from jurisdiction. ${ }^{37}$ And it did. In a body of arbitration jurisprudence, the Supreme Court has declared the FAA a "national policy favoring arbitration."38 Corporate America has embraced arbitration not only for the private resolution of disputes with other businesses, but also as the process of choice in dealing with disputes with consumers or employees. Unless those consumers or employees act together. Judicial hostility has arguably transformed into infatuation with arbitration. ${ }^{39}$ Unless it is class arbitration. Corporate entities, which seek arbitration as to individuals, generally resist arbitration when pursued by individuals on a class basis, and they complain of the risks, akin to those raised by individual plaintiffs as in Gilmer, of the arbitrariness of one arbitrator's power in a class case. ${ }^{40}$

consumer and employment settings).

36. See, e.g., EEOC v. Waffle House, Inc., 534 U.S. 279, 296 n.10 (2002) ("To the extent the Court of Appeals construed an employee's agreement to submit his claims to an arbitral forum as a waiver of the substantive statutory prerogative of the EEOC to enforce those claims for whatever relief and in whatever forum the EEOC sees fit, the court obscured this crucial distinction and ran afoul of our precedent.”); Mitsubishi Motors Corp. v. Soler Chrysler-Plymouth, Inc., 473 U.S. 614, 628 (1985) ("By agreeing to arbitrate a statutory claim, a party does not forgo the substantive rights afforded by the statute; it only submits to their resolution in an arbitral, rather than a judicial, forum.").

37. Gilmer, 500 U.S. at 24 (explaining that the FAA's "purpose was to reverse the longstanding judicial hostility to arbitration agreements ... and to place arbitration agreements upon the same footing as other contracts”); $c f$. Wilko v. Swan, 346 U.S. 427, 438 (1953) (refusing to enforce predispute agreement to arbitrate Securities Act claims because of doubts that statutory rights could be effectively enforced in arbitration), overruled by Rodriguez de Quijas v. Shearson/Am. Express, Inc., 490 U.S. 477 (1989).

38. Southland Corp. v. Keating, 465 U.S. 1 , 10 (1984) (explaining that the FAA "declared a national policy favoring arbitration”). The Court's interpretation of the FAA, however, has been widely criticized as overly broad. See, e.g., Margaret L. Moses, Statutory Misconstruction: How the Supreme Court Created a Federal Arbitration Law Never Enacted by Congress, 34 FLA. ST. U. L. REV. 99, 105-08 (2006) (analyzing the FAA's legislative history to illustrate Congress intended a narrow application of the FAA to disputes among merchants).

39. See Stempel, supra note 5 (describing the Supreme Court's modern construction of the FAA)

40. See David Horton, Arbitration as Delegation, 86 N.Y.U. L. REV. 437, 461 (2011) ("For companies, however, the most advantageous aspect of their control over arbitral procedures was the chance to prohibit class action lawsuits.”). 


\section{B. Federal Arbitration Law and Class Actions}

The FAA, in text a relatively simple procedural statute that provides for the enforcement of valid arbitration contracts, is silent on any treatment of class actions or class relief. ${ }^{41}$ Modern class actions have been a vital procedural option for aggregate party litigation claims since adopted in Rule 23 of the Federal Rules of Civil Procedure in $1966 .{ }^{42}$

The question of the interplay between class actions and arbitration came before the Supreme Court indirectly in the early 1980s in Southland. ${ }^{43}$ Southland involved a class action initially filed in state court by franchisees of 7-Eleven stores in California. ${ }^{44}$ The defendant petitioned to compel arbitration, and the plaintiffs sought class status in arbitration. ${ }^{45}$ The California Supreme Court denied arbitration, ruling that the state statute required judicial consideration of franchise disputes. ${ }^{46}$ The court, nevertheless, also addressed the concept of classwide arbitration, expressing concerns over class waivers and recognizing class arbitration as a viable option akin to consolidated judicial proceedings. $^{47}$ On the preemption issue, the U.S. Supreme Court reversed, holding the FAA preempted the conflicting state law. ${ }^{48}$ Regarding the question of "superimposing class action procedures on a contract arbitration," 49 the Court recognized that class arbitration was permissible under California state law. ${ }^{50}$ Concluding that a federal question was not involved, the U.S. Supreme Court determined it lacked jurisdiction to address whether the FAA bars class action arbitration. ${ }^{51}$

In 2003, class arbitration again came before the Supreme Court in Green Tree Financial Corp. v. Bazzle. ${ }^{52}$ The consumer lending contract

\footnotetext{
41. See 9 U.S.C. §§ 1-16 (2006).

42. See supra note 24 and accompanying text.

43. 465 U.S. 1 (1984).

44. Id. at $3-4$.

45. Id. at 4.

46. Keating v. Superior Court, 645 P.2d 1192, 1203-04 (1982) ("We simply reject... that those [FAA] principles are so unyielding as to require enforcement of an agreement to arbitrate a dispute over the application of a regulatory statute which a state legislature, in conformity with analogous federal policy, has decided should be left to judicial enforcement."), rev'd in part, appeal dismissed in part sub nom. Southland, 465 U.S. 1.

47. Id. at $1207-09$.

48. Southland, 465 U.S. at 16.

49. Id. at 9.

50. Id. at 9 n. 4 .

51. Id. at 9 .

52. 539 U.S. 444, 447 (2003) (plurality opinion).
} 
in Bazzle contained a standard arbitration clause but appeared silent as to class actions. ${ }^{53}$ The South Carolina Supreme Court held that the case could proceed in class arbitration, reasoning that such a process effectuated both the arbitration agreement and operative state consumer protection law, which allowed class claims. ${ }^{54}$ The U.S. Supreme Court, however, in a plurality decision (Justices Breyer, Scalia, Souter, and Ginsburg) concluded that the FAA required the arbitrator to determine "whether the arbitration contracts forbid class arbitration.",55 PostBazzle, courts and arbitration providers presumed that arbitrators were to interpret arbitration contracts to determine the parties' intent regarding class arbitration and that, implicitly, class-wide arbitration was a viable procedure under the FAA. ${ }^{56}$

In 2010, the Court's sentiment toward class arbitration appeared to take a sharp turn in Stolt-Nielsen. ${ }^{57}$ Seemingly similar to Bazzle, the underlying arbitration agreement in Stolt-Nielsen was silent on the issue of class arbitration. ${ }^{58}$ On the basis that the agreement did not preclude class arbitration, the arbitration panel ordered class arbitration. ${ }^{59}$ Writing for the 5-3 majority, Justice Alito (joined by Justices Roberts, Scalia, Kennedy, and Thomas) seemingly departed from Bazzle and held that arbitrators exceeded their authority or acted in manifest disregard in imposing class arbitration absent an (express) agreement by the parties to allow class arbitration. ${ }^{60}$ Marginalizing Bazzle as a mere plurality

53. Id. at $448-50$.

54. Bazzle v. Green Tree Fin. Corp., 569 S.E.2d 349, 360-61 (S.C. 2002), vacated 539 U.S. 444. The court also acknowledged that to interpret silence as a ban on class actions in arbitration would allow the drafting party to "effectively prevent class actions against it without having to say it was doing so in the agreement" and that express bans on class-wide arbitration would "undermine[] principles favoring expeditious and equitable case disposition." $I d$. at 360 \& n.21 ("Under those circumstances, parties with nominal individual claims, but significant collective claims, would be left with no avenue for relief and the drafting party with no check on its abuses of the law.”).

55. Bazzle, 539 U.S. at 453-54 (plurality opinion); see also id. at 454-55 (Stevens, J., concurring in the judgment and dissenting in part) (stating that the FAA did not preclude a state court from authorizing class arbitration).

56. See Garcia v. DIRECTV, Inc., 115 Cal. App. 4th 297, 304 n.4 (2004) (following Bazzle and stating that "[i]mplicit in Bazzle is the notion that, absent a class action waiver, classwide arbitration is proper under the FAA"). After Bazzle, leading arbitration providers promulgated rules governing their administration of arbitral class actions. See supra note 4 and accompanying text.

57. 130 S. Ct. 1758 (2010).

58. Id. at 1766.

59. Id.

60. Id. at 1772, 1775-76 ("Unfortunately, the opinions in Bazzle appear to have baffled the parties .... . For one thing, the parties appear to have believed that the judgment in Bazzle requires an arbitrator, not a court, to decide whether a contract permits class arbitration. . . Bazzle did not establish the rule to be applied in deciding whether class arbitration is permitted.”). 
opinion, the Court proceeded to critique class arbitrations and described "just some of the fundamental” differences between bilateral and class arbitrations as "too great for arbitrators to presume."

After Stolt-Nielsen, a contract silent on arbitration could not be construed to authorize class arbitration absent extrinsic evidence authorizing such. Meanwhile, lawsuits challenging the enforceability of "express bans" on class actions or "class action waivers" in arbitration contracts continued to mount in the lower state and federal courts. ${ }^{62}$ Courts had largely divided on whether the class waivers were to be enforced "according to their terms" pursuant to the FAA's command, or were subject to scrutiny under state contract law. The California Supreme Court's rule on class waivers was made clear through a decision in Discover Bank v. Superior Court, which held a class action waiver, specifically in adhesion consumer contracts involving small amounts of damages and imposed by a party with superior bargaining power, unconscionable. ${ }^{63}$ After Discover Bank, California courts regularly found waivers of class litigation or arbitration unconscionable. ${ }^{64}$ Against this backdrop, the consumer-plaintiffs in Concepcion sought class arbitration. ${ }^{65}$

\section{Class ACtion WAIVERs: FAA PREEMPTION VS. STATE UNCONSCIONABILITY}

\section{A. AT\&T Mobility LLC v. Concepcion}

In 2002, Vincent and Liza Concepcion entered into a contract with AT\&T for the sale and service of cellular telephones. ${ }^{66}$ The phones were advertised as free, but the Concepcions were charged \$30.22 in sales

61. Id. at 1776. "[C]lass-action arbitration changes the nature of arbitration to such a degree that it cannot be presumed the parties consented to it by simply agreeing to submit their disputes to an arbitrator.” Id. at 1775.

62. See Brief for Respondents at 18, AT\&T Mobility LLC v. Concepcion, 131 S. Ct. 1740 (2011) (No. 09-893), 2010 WL 4411292 at *18 (“[C]lass-action bans have been held unenforceable under the common law of twenty States ....”).

63. 113 P.3d 1100, 1110 (2005), abrogated by Concepcion, 131 S. Ct. 1740.

64. See, e.g., Shroyer v. New Cingular Wireless Servs., Inc., 498 F.3d 976, 978-79 n.1 (9th Cir. 2007) (citing ten California cases also concluding that a class arbitration waiver in a consumer contract was unconscionable), abrogated by Concepcion, 131 S. Ct. 1740; Cohen v. DirecTV, Inc., 48 Cal. Rptr. 3d 813, 822-23 (2006), abrogated by Concepcion, 131 S. Ct. 1740.

65. $131 \mathrm{~S}$. Ct. at $1744-45$.

66. Id. at 1744 . 
tax. ${ }^{67}$ The Concepcions filed a complaint that was eventually consolidated with a class action lawsuit against AT\&T in federal court in California alleging false advertising and fraud. ${ }^{68}$ AT\&T moved to compel arbitration pursuant to the arbitration provision in the purchase and sale contract. $^{69}$ The arbitration clause required that claims be brought in an "individual capacity, and not as a plaintiff or class member in any purported class or representative proceeding."70 The contract also provided for an informal dispute-resolution process whereby customers could complete a one-page form available on AT\&T's website. ${ }^{71}$ If the dispute was not resolved within thirty days, then the customer had the option of small claims court or arbitration. ${ }^{72}$ Pursuant to the provision, arbitration would take place in the county in which the customer was billed, and AT\&T agreed to pay all costs for non-frivolous claims and not seek reimbursement for its attorney fees. ${ }^{73}$ Further, if the Concepcions received an award larger than AT\&T's last settlement offer, AT\&T would pay a guaranteed minimum recovery of $\$ 7,500$ and double the attorney's fees. ${ }^{74}$ The plaintiffs opposed the motion to compel arbitration, alleging it was unlawful and exculpatory based on California law. $^{75}$

\section{B. Lower Court Rulings}

Although the district court acknowledged that AT\&T's informal dispute resolution process was "quick, [and] easy to use," it denied AT\&T's motion to compel. ${ }^{76}$ The district court found the arbitration provision unconscionable under California law "because AT\&T had not

67. Id.

68. Id.

69. Id. at $1744-45$.

70. Id. at 1744 (quoting Brief for Respondents, supra note 62, at 3) (internal quotation marks omitted).

71. Id. AT\&T unilaterally modified the agreement several times during the litigation, including one modification nine months after the Concepcions filed suit, adding more "consumer-friendly" provisions through a bill stuffer procedure. Brief for Respondents, supra note 62, at 7.

72. Concepcion, 131 S. Ct. at 1744.

73. Id.

74. Id.; cf. Brief for Respondents, supra note 62, at 4-6 (asserting that AT\&T's dispute process deters consumers from obtaining legal representation and noting the low number of consumer arbitrations-less than 0.0029 percent of AT\&T's 90 million customers-filed over a five-year span under the process despite widespread consumer complaints about the company to the Better Business Bureau).

75. Concepcion, $131 \mathrm{~S}$. Ct. at 1745.

76. Id. 
shown that bilateral arbitration adequately substituted for the deterrent effects of class actions."77 The Ninth Circuit affirmed, holding that the class action waiver in AT\&T's consumer contract was unconscionable under the California Supreme Court's decision in Discover Bank and that the FAA did not preempt application of the state unconscionability laws to arbitration contracts. ${ }^{78}$ According to the Ninth Circuit, "applying California's generally applicable contract law to refuse enforcement of the unconscionable class action waiver in this case does not stand as an obstacle to the purposes or objectives of the [FAA], and is, therefore, not impliedly preempted."79

\section{The U.S. Supreme Court}

The formal question before the Supreme Court was "whether the FAA prohibits States from conditioning the enforceability of certain arbitration agreements on the availability of class-wide arbitration procedures." 80 More specifically, the Court addressed "whether $\S 2$ preempts California's rule classifying most collective-arbitration waivers in consumer contracts as unconscionable"- the "Discover Bank rule.,"81

In reversing the Ninth Circuit, a majority of the Supreme Court held that the FAA preempted the Discover Bank rule because it "stands as an obstacle to the accomplishment" of the FAA's purposes and objectives. ${ }^{82}$ While not finding a direct conflict between the state unconscionability rule and the FAA, ${ }^{83}$ Justice Scalia, writing for the 5-4 majority (joined by Justices Roberts, Kennedy, Thomas, and Alito), declared that "[r]equiring the availability of class-wide arbitration interferes with

77. Id. (citing Laster v. T-Mobile USA, Inc., No. 05CV1167 DMS (AJB), 2008 WL 5216255, at *14 (S.D. Cal. Aug. 11, 2008), rev'd by Concepcion, 131 S. Ct. 1740).

78. Id. The Ninth Circuit explained that class action waivers were on the same footing regardless of whether they occurred in the arbitration context or outside of it. Id. (citing Laster v. AT\&T Mobility LLC, 584 F.3d 849, 858 (9th Cir. 2009), rev'd sub nom. Concepcion, 131 S. Ct. 1740).

79. Laster, 584 F.3d at 858 (quoting Shroyer v. New Cingular Wireless Servs., Inc., 498 F.3d 976, 993 (9th Cir. 2007), abrogated by Concepcion, 131 S. Ct. 1740) (internal quotation marks omitted).

80. Concepcion, $131 \mathrm{~S}$. Ct. at 1744.

81. Id. at 1746 .

82. Id. at 1753 (quoting Hines v. Davidowitz, 312 U.S. 52, 67 (1941)).

83. "The FAA does not contain an express preemption clause." Christopher R. Drahozal, Federal Arbitration Act Preemption, 79 IND. L. J. 393, 397-98 (2004) (explaining, however, that traditional preemption analysis examines whether a conflict exists between the state and federal rule). 
fundamental attributes of arbitration and thus creates a scheme inconsistent with the FAA.» ${ }^{84}$ Justice Scalia spoke of arbitration under the FAA as a streamlined, informal, and inexpensive proceeding between two parties, seemingly oblivious of the trend in commercial arbitration toward formalized and protracted processes. ${ }^{85}$ Justice Scalia, however, also cited additional complexities in administering class arbitration and advised that "class arbitration greatly increases risks to defendants ... [and] is poorly suited to the higher stakes of class litigation." 86 Projecting the defendant's perspective, Justice Scalia noted that "[w]e find it hard to believe that defendants would bet the company with no effective means of review, and even harder to believe that Congress would have intended to allow state courts to force such a decision." ${ }^{87}$ Obliquely addressing the savings clause, the Court noted that the FAA "permits agreements to arbitrate to be invalidated by 'generally applicable contract defenses, such as fraud, duress, or unconscionability,' [although] not by defenses that apply only to arbitration or that derive their meaning from the fact that an agreement to arbitrate is at issue." 88

Justice Thomas, on the other hand, has long maintained that the FAA does not apply in state courts. ${ }^{89}$ Nevertheless, he "reluctantly" joined the Court's opinion, concurring in the judgment but otherwise contending that the FAA savings clause, and thus state contract defenses, apply at the formation stage of the arbitration agreement. ${ }^{90}$ Although he recognized class waivers were exculpatory under Discover Bank, he argued that California's law reflected public policy rather than the making of the agreement. ${ }^{91}$ Thomas asserted that courts could not refuse to enforce arbitration agreements because of such policy even if the policy applied to any contract. ${ }^{92}$

84. Concepcion, $131 \mathrm{~S}$. Ct. at 1748.

85. Id. at 1749; see also Stipanowich, supra note 18, at 8-9 (discussing generally the "streamlined" concept).

86. Concepcion, 131 S. Ct. at 1752.

87. Id.

88. Id. at 1746 (quoting Doctor's Assocs., Inc. v. Casarotto, 517 U.S. 681, 687 (1996)).

89. See, e.g., Allied-Bruce Terminix Cos. v. Dobson, 513 U.S. 265, 285 (1995) (Thomas, J., dissenting).

90. Concepcion, 131 S. Ct. at 1754-55 (Thomas, J., concurring) (citing Wyeth v. Levine, 555 U.S. 555, 582-604 (2009) (Thomas, J., concurring in the judgment)) (“[A]lthough I adhere to my views on purposes-and-objectives pre-emption, I reluctantly join the Court's opinion.”).

91. Id. at 1756.

92. Id. at $1754-55$. 
In dissent, Justice Breyer (joined by Justices Ginsburg, Sotomayor, and Kagan) argued that the California law was consistent with the FAA and applied equally to contracts to arbitrate or litigate. ${ }^{93}$ Breyer argued that "class arbitration is consistent with the use of arbitration.... [And it] is well known in California and followed elsewhere."94 They challenged the majority's assertion that class arbitration is fundamentally incompatible with arbitration and proposed that the proper comparison is class arbitration to judicial class actions, not bilateral arbitration. ${ }^{95}$ In response to the majority's critique of class arbitration, Justice Breyer noted the countervailing advantages of the process, stating that "a single class proceeding is surely more efficient than thousands of separate proceedings for identical claims.... [I]f speedy resolution of disputes were all that mattered, then the Discover Bank rule would reinforce, not obstruct, that objective of the Act." ${ }^{96}$ He recognized, as a practical matter, that most small-dollar claimants subject to class waivers would simply abandon their claims and go without legal representation. ${ }^{97}$ Lastly, Justice Breyer pointed to the federalism concerns raised by the decision, urging that through the FAA savings clause "Congress retained for the States an important role incident to agreements to arbitrate.",98

\section{Defining Concepcion}

The Concepcion decision has been both lauded by businesses and derided by others as a license for wide-spread, small-claims, corporate fraud. ${ }^{99}$ In the context of the Supreme Court's arbitration jurisprudence,

93. Id. at 1757-58 (Breyer, J., dissenting).

94. Id. at 1758 (citing AAA and JAMS class arbitration rules as support).

95. See id. at 1759.

96. Id. at $1759-60$.

97. Id. at 1760-61 (noting Discover Bank's recognition that, under class waivers, "the terms of consumer contracts can be manipulated to insulate an agreement's author from liability for its own frauds by 'deliberately cheat[ing] large numbers of consumers out of individually small sums of money”” (quoting 113 P.3d 1100, 1110 (2005), abrogated by Concepcion, 131 S. Ct. 1740)).

98. Id. at 1762 (citing 9 U.S.C. $§ 2$ (2006)).

99. See, e.g., Cole, supra note 35, at 463 (describing Concepcion as the "nail in the coffin" of class arbitration); see also Frank Blechschmidt, Comment, All Alone in Arbitration: AT\&T Mobility v. Concepcion and the Substantive Impact of Class Action Waivers, 160 U. PA. L. REV. 541, 542 (2012) (arguing that "[b]ecause class actions are so intimately linked to the vindication of substantive rights, the Court should not have unilaterally made a policy decision as to when the use of class proceedings is appropriate”). Businesses, on the other hand, praised the decision, with AT\&T stating that "its arbitration program is 'free, fair, easy to use and consumer friendly."” Robert Barnes, Supreme Court Says Arbitration Agreements Can Ban Class-Action Efforts, WASHINGTON Post, Apr. 27, 2011, http://www.washingtonpost.com/politics/supreme-court-says-arbitration- 
the case certainly affirms the Court's deference to arbitration and reluctance to recognize exceptions to the presumption of arbitral enforceability. The Court's perception is that arbitration is quick, informal, and cheap, but that, based on reports from the commercial arbitration community, class arbitration does not align with these ideals. ${ }^{100}$ The majority's argument that class actions are ill-suited for arbitration because of the high stakes involved, the limited review of the FAA, and the attendant increased risks to employers, were all raised as concerns by the plaintiff in the Gilmer case, yet the Gilmer Court rejected them. ${ }^{101}$ The Court sent a mixed message that arbitration with its limited review is fine for fundamental individual rights, but not for a business entity. Perhaps this case can be distinguished because of the "consumer-friendly" aspects of the AT\&T commercial arbitration clause that address consumer interest concerns yet avoid class actions (despite the risk of unconscionability in California). Yet the Court articulated a position, as it did in Stolt-Nielsen, that class arbitration is fundamentally different from bilateral litigation and, thus, contrary to the FAA.

\section{POST-CONCEPCION: FAA PREEMPTION SCOPE, LIMITS, AND THE FUTURE OF CLASS ARBITRATION}

Concepcion appeared to require that courts enforce class action waivers, even under circumstances where the bans on collective relief would otherwise impose unconscionable results. In ruling that the FAA preempts state law that would otherwise invalidate class action waivers, does Concepcion foreclose collective action by virtue of the arbitration contract? What is left for the states and the savings clause provision for generally applicable state-law defenses serving as a check on arbitration agreements under section 2? Does Concepcion apply where a class waiver denies parties the ability to vindicate their rights? A number of state and federal courts have upheld class action waivers contained in consumer arbitration contracts despite concerns that the provisions violated state law. ${ }^{102}$ Yet other courts and commentators are more circumspect in their reading of Concepcion and are defining limits to its

\footnotetext{
agreements-can-ban-class-action-efforts/2011/04/27/AFp23j0E_story.html.

100. See Barnes, supra note 99. As it did in Stolt-Nielsen, the Concepcion Court divided on this issue along political lines. See id.; see also supra notes 5-28 and accompanying text.

101. Concepcion, 131 S. Ct. at 1749-52 \& n.5 (citing Gilmer v. Interstate/Johnson Lane Corp., 500 U.S. 20, 30-33 (1991)).

102. See infra Part IV.A.
} 
preemptive scope. ${ }^{103}$ Congressional responses to the concerns raised by Concepcion are also in the making. ${ }^{104}$ The following section describes judicial responses to Concepcion, outlining its application as well as its potential limits.

\section{A. Cases Upholding Class Action Waivers Based on FAA Preemption Even If State Law Would Invalidate Such Waivers}

After Concepcion, a rubber-stamp effect seemed to ensue in the courts addressing the enforceability of class action waivers in arbitration agreements. Courts largely considered their rulings bound to follow Concepcion, even where state law would invalidate the contractual bans. The Eleventh Circuit, in Cruz v. Cingular Wireless, LLC, considered a consumer class action lawsuit against a cell phone company where the underlying agreement contained a class action waiver and requirement for individual arbitration. ${ }^{105}$ The plaintiffs there argued that the class action waiver embedded in the arbitration provision frustrated their ability to vindicate their rights under the state deceptive trade practices statute. ${ }^{106}$ Although the Cruz court acknowledged that the class action waiver in the consumer arbitration contract would be invalid under state law as contrary to public policy, it determined itself bound, under Concepcion, to enforce the class action waiver and ruled that the FAA preempted the state law, which stood as an obstacle to the accomplishment of the FAA's objective of promoting arbitration. ${ }^{107}$

In Bernal v. Burnett, the United States District Court for the District of Colorado considered class certification for former students of online trade schools who alleged that the defendant-operator's business practices violated state deceptive trade practices laws. ${ }^{108}$ The enrollment

\footnotetext{
103. See infra Part IV.B.1-3.

104. See infra Part V.

105. 648 F.3d 1205, 1206-07 (11th Cir. 2011).

106. Id. at 1212 (noting the plaintiffs' argument that the waiver would exculpate defendants from liability under state law and hinder the statute's remedial purposes).

107. Id. (noting that Concepcion rejected the public policy argument that the class action waiver would operate to exculpate defendants from liability in cases of small-value claims that will go undetected and unprosecuted); id. at 1215 (stating that even where state law "would require the availability of classwide arbitration ... such a state rule is inconsistent with and thus preempted by FAA § 2”); see also Litman v. Cellco P'ship, 655 F.3d 225, 231-32 (3d Cir. 2011) (holding a common law rule imposing class arbitration despite contractual prohibition of class or collective actions preempted by the FAA).

108. 793 F. Supp. 2d 1280, 1282 (D. Colo. 2011). The plaintiffs initially filed for class arbitration before the AAA. Id. at 1283. The arbitrator denied arbitration because, under Stolt-
} 
documents, considered part of an adhesion contract, included an arbitration provision and class waiver. ${ }^{109}$ In seeking class recognition, the plaintiffs argued that they could only realistically pursue their claims as a class - in arbitration or in court - and that the confidential nature of arbitration on an individualized basis would make it impossible to pursue their claims otherwise. ${ }^{110}$ The court conceded that, but for Concepcion, it would have found the arbitration agreement unconscionable. ${ }^{111}$ Ruling itself bound to deny plaintiffs' desired relief, the court acknowledged the following:

There is no doubt that Concepcion was a serious blow to consumer class actions and likely foreclosed the possibility of any recovery for many wronged individuals.... [T] The Supreme Court considered the fact that the Concepcions and other class plaintiffs would be denied any recovery by its ruling, and ruled against the class plaintiffs nonetheless. ${ }^{12}$

Extending Concepcion to the employment context, the United States District Court for the Northern District of California, in Lewis v. UBS Financial Services Inc., dismissed an employee's putative class action, holding that a class action wavier was enforceable even if unconscionable under California law. ${ }^{113}$ Even as to federal claims under the Servicemembers Civil Relief Act (SCRA), ${ }^{114}$ the United States District Court for the District of New Jersey, in Wolf v. Nissan Motor Acceptance Corp., relied upon Concepcion in upholding the class action waiver in an arbitration agreement between a car dealer and a military serviceman. ${ }^{115}$ The plaintiff argued that enforcement of the class action waiver undermined the purposes and policies of the SCRA, which was designed to protect military service members. ${ }^{116}$ The court reasoned that because the SCRA does not address class waivers, and thus does not preclude them, under Concepcion, the arbitration clause in the contract is

\footnotetext{
Nielsen, there was no explicit agreement to class arbitration. Id. Thereafter, the plaintiffs filed a class action in the district court. Id. at 1284.

109. Id. at 1283.

110. Id. at $1287-88$.

111. Id.

112. Id. at 1288.

113. No. C 10-04867 SBA, 2011 WL 4727795, at *4 (N.D. Cal. Sept. 30, 2011).

114. 50 U.S.C. app. §§ 501-596 (2006).

115. No. 10-CV-3338(NLH)(KMW), 2011 WL 2490939, at *7 (D.N.J. June 22, 2011).

116. Id. at $* 5$.
} 
valid. ${ }^{117}$ Similarly, the United States District Court for the Northern District of California, in In re California Title Insurance Antitrust Litigation, granted a motion to compel individual arbitration of a class action lawsuit after Concepcion where the arbitration agreements at issue between title insurance companies and a consolidated group of policy purchasers were silent as to class arbitration. ${ }^{118}$ The court noted that, prior to Concepcion, it would have held the arbitration agreements unconscionable, but after the decision, it must compel arbitration "even in the absence of the opportunity for plaintiffs to bring their claims as a class action."119

Finally, even motions seeking to compel arbitration brought after Concepcion that would have been futile prior to Concepcion have been granted. The United States District Court for the Northern District of California, in Estrella v. Freedom Financial, granted such a motion despite plaintiffs' objections as to waiver because of the defendant's failure to seek an order compelling arbitration during the two years of litigation. ${ }^{120}$ The court noted that the defendants did not waive their right to compel arbitration because, prior to Concepcion, they were not acting "inconsistently with a known existing right to compel arbitration.",21 Thus, where an express waiver on class relief is clear, courts are likely to compel individual arbitration or no arbitration at all. ${ }^{122}$

\section{B. Can Concepcion Be Distinguished?-Limits on Class Action Waivers}

Despite Concepcion's apparent mandate to enforce class action waivers under the FAA, courts have declined to enforce class action bans in cases where collective action was deemed necessary to vindicate the right in question.

\footnotetext{
117. Id. at *5, *7.

118. No. 08-1341 JSW, 2011 WL 2566449, at *2-3 (N.D. Cal. June 27, 2011).

119. Id. at $* 2$.

120. No. C 09-03156 SI, 2011 WL 2633643, at *4-5 (N.D. Cal. July 5, 2011).

121. Id. at $* 5$.

122. See, e.g., Hopkins v. World Acceptance Corp., 798 F. Supp. 2d 1339, 1348-50 (N.D. Ga. 2011). The loan agreement between the consumer-borrower and the lender contained an extensively detailed arbitration agreement typed in ALL CAPITAL LETTERS (also known as screaming) that excluded class actions. Id. at 1342-43. The plaintiff alleged that the defendant violated, inter alia, the state deceptive trade practices act and Truth in Lending Act. Id. at 1342. In holding the class action waiver enforceable, the court noted that the waiver was clear, and under the standards established in Concepcion, the agreement was not unconscionable. Id. at 1348.
} 


\section{California Courts Conflicted on When to Enforce Class Action Waivers}

Although the Supreme Court held that the California Supreme Court's Discover Bank rule invalidating class action waivers was preempted under the FAA, California lower courts continue to struggle with enforcing class action waivers and have found circumstances in which to distinguish Concepcion.

\section{a. State Private Attorney General Actions}

A California Court of Appeal, in Brown v. Ralphs Grocery Co., held that Concepcion does not apply to representative actions under the state Private Attorney General Act of 2004 (PAGA). ${ }^{123}$ In Brown, an employee filed a class and representative action under PAGA, alleging violations under the state Labor Code. ${ }^{124}$ The defendant-employer sought to compel individual arbitration pursuant to the arbitration policy, which also excluded class actions. ${ }^{125}$ The court rejected the claim that the waiver was unconscionable after Concepcion; however, it held the waiver was not effective as to precluding the employee's right to pursue a representative claim under PAGA. ${ }^{126}$ The court stated that "[Concepcion] does not purport to deal with the FAA's possible preemption of contractual efforts to eliminate representative private attorney general actions to enforce the Labor Code. ... PAGA creates a statutory right for civil penalties for Labor Code violations 'that otherwise would be sought by state labor law enforcement agencies.”,127 The court likened the aggrieved employee's role to that of a proxy or agent of state labor law enforcement agencies. ${ }^{128}$ In contrast to Concepcion, which involved waiving the private right of an individual, Brown involved a non-waivable public right. ${ }^{129}$ Similar to how the EEOC is not barred by an employee's arbitration agreement from filing

123. 128 Cal. Rptr. 3d 854, 856 (Cal. Ct. App. 2011), cert. denied, 2012 WL 136923 (U.S. Apr. 16, 2012).

124. Id.

125. Id. at $856-57$.

126. Id. at 859,863

127. Id. at 860-61 (quoting Amalgamated Transit Union, Local 1756 v. Superior Court, 209 P.3d 937, 943 (Cal. 2009)).

128. Id. at 861 .

129. Id. (noting that a state law "established for a public reason cannot be contravened by private agreement” (quoting CAL. CIV. CODE $\S 3513$ (West 1997)) (internal quotation marks omitted)). 
suit under federal anti-discrimination laws, ${ }^{130}$ private citizens are "deputized" as private attorneys general to bring representative actions as a means of public enforcement of the state's labor code. ${ }^{131}$ Ultimately, the court held that a private contractual agreement-the arbitration agreement — cannot serve to contravene a publicly established law. ${ }^{132}$

\section{b. Public Injunctive Relief}

The exception for PAGA claims under Brown is not universally accepted by the California courts. For example, the plaintiff in Nelson $v$. AT\&T Mobility LLC sought to distinguish Concepcion by filing a class action lawsuit seeking public injunctive relief under California's unfair competition law and Consumers Legal Remedies Act and by invoking the analogy to the decisions exempting PAGA claims. ${ }^{133}$ Despite the plaintiff's claim that seeking to enforce public rights would not conflict with the FAA, the court enforced the arbitration clause with a class action waiver. ${ }^{134}$ Similarly, the court, in Kaltwasser v. AT\&T Mobility $L L C$, upheld an arbitral class waiver even though the plaintiff argued that enforcing the class waiver would prevent him from vindicating claims for public injunctive relief under state law, reasoning that state law could not prohibit arbitrating particular claims. ${ }^{135}$

\section{State Contract Law Defenses: Unconscionable but Not “Anti-} Arbitration"

Concepcion cast doubt on the continued application of section 2 contract law defenses, specifically unconscionability. ${ }^{136}$ Concepcion invalidated the California unconscionability standard to class waivers because it determined the defense applied "only to arbitration or derive[d] [its] meaning from the fact that an agreement to arbitrate [wa]s at issue."137 Notwithstanding this ambiguous test, some courts have

\footnotetext{
130. See EEOC v. Waffle House, Inc., 534 U.S. 279, 296-98 (2002).

131. Brown, 128 Cal. Rptr. 3d at 862.

132. See id. at 860-61.

133. No. C 10-4802 TEH, 2011 WL 3651153, at *1, *3 (N.D. Cal. Aug. 18, 2011).

134. Id. at *3-4.

135. No. C 07-00411, 2011 WL 4381748, at*6-7 (N.D. Cal. Sept. 20, 2011).

136. See AT\&T Mobility LLC v. Concepcion, 131 S. Ct. 1740, 1746-53 (2011) (discussing the unconscionability doctrine as argued by the Concepcions).

137. Id. at 1743 (citing Doctor's Assocs., Inc. v. Casarotto, 517 U.S. 681, 687 (1996)).
} 
continued to apply unconscionability as a general defense to test an arbitration contract's validity. ${ }^{138}$

The court, in Kanbar v. O’Melveny \& Myers, found the Dispute Resolution Program provisions in an individual and class employment discrimination claim unconscionable. ${ }^{139}$ The provisions included: (a) a one-year claim-filing notice period, which essentially shortened the statute of limitations for employment-related claims; (b) a confidentiality clause that prohibited any employee from assisting in another employee's case; (c) an exemption for the employer from arbitration; and (d) a bar on claims to administrative agencies, other than discrimination claims to the EEOC or a comparable state agency. ${ }^{140}$ Rejecting that the FAA preempts its unconscionability determination, the court reasoned that a rule is anti-arbitration if it "interferes with [the] fundamental attributes of arbitration"-in particular, its informality, expeditiousness, and relative inexpensiveness. ${ }^{141}$ Thus, state unconscionability may still serve to invalidate arbitration agreements because, as long as the invalidation does not interfere with the fundamental attributes of arbitration, it will not conflict with Concepcion and, thus, will not be subject to preemption under the FAA. ${ }^{142}$

Arbitration provisions that include class waivers have also been invalidated by standard contract defenses, such as lack of mutual assent, where the provision was too vague to provide adequate notice. ${ }^{143}$ "Thus, in the aftermath of [Concepcion], state courts remain free to decline to enforce an arbitration provision by invoking traditional legal doctrines governing the formation of a contract and its interpretation."144

138. Mission Viejo Emergency Med. Assocs. v. Beta Healthcare Grp., 128 Cal. Rptr. 3d 330, 339-41 \& n.4 (Cal. Ct. App. 2011) (interpreting Concepcion as preempting state unconscionability only to the extent that the defense "applies 'only to arbitration or ... derive[s] [its] meaning from the fact that an agreement to arbitrate is at issue'" and finding the arbitration provision in the physician group's malpractice insurance contract was not unconscionable (alterations in original) (quoting Concepcion, 131 S. Ct. at 1743)).

139. No. C-11-0892 EMC, 2011 WL 2940690, at *12 (N.D. Cal. July 21, 2011).

140. Id. at *2-3.

141. Id. at $* 4$ (quoting Concepcion, $131 \mathrm{~S}$. Ct. at 1748 ) (internal quotation marks omitted).

142. Id. at *6 ("In short, arbitration agreements are still subject to unconscionability analysis. ... . [T] he court rejects [the defendant's] contention that a challenge to an arbitration agreement must be rejected if it means that the agreement will not be enforced according to its terms. The doctrine of unconscionability can override the terms of an arbitration agreement and the parties' expectations in connection therewith.”).

143. NAACP of Camden Cnty. E. v. Foulke Mgmt. Corp., 24 A.3d 777, 793-96 (N.J. Super. Ct. App. Div. 2011) (invalidating arbitration provisions not as contrary to public policy, but for lack of mutual assent, as the provisions were too vague to provide adequate notice).

144. Id. at 792; see also Williams v. Securitas Sec. Servs. USA, Inc., No. 10-7181, 2011 WL 


\section{Vindication of Competing Federal Statutory Rights}

While the FAA may preempt state law claims, the pro-arbitration policy does not necessarily prevail with competing federal statutory rights. Accordingly, some courts have refused to enforce class action waivers in arbitration agreements by relying on the vindication of federal statutory rights doctrine. ${ }^{145}$

\section{a. Title VII: Pattern or Practice Claims}

Chen-Oster v. Goldman, Sachs \& Co. involved a question over whether the federal priority for arbitration applies where rights created by a competing federal statute are infringed by an arbitration agreement. $^{146}$ The court noted that the substantive nature of the plaintiff's Title VII pattern or practice discrimination claim could only be pursued on a class basis. ${ }^{147}$ The substantive right was not the right to proceed on a class basis, but rather the right to vindicate a claim. ${ }^{148}$ On the grounds that "an arbitration provision [that] 'precludes plaintiffs from enforcing their statutory rights' is unenforceable," the court held that Concepcion was not applicable to federal statutory claims that can only be vindicated on a class basis. ${ }^{149}$

\section{b. Fair Labor Standards Act: Cost of Action and Ability to Vindicate Rights}

Judge Wood of the Southern District of New York relied on the vindication of rights doctrine to preserve a class claim in Sutherland $v$. Ernst \& Young LLP. ${ }^{150}$ Judge Wood invalidated a class waiver in an employment agreement that would have precluded class litigation to

2713741, at *3 (E.D. Pa. July 13, 2011) (distinguishing Concepcion by holding that the arbitration agreement between the security company employees and their employer was not valid because it was "a confusing and unfair communication with the class of possible plaintiffs").

145. See infra Part IV.B.3.a-c. It is unclear under Concepcion whether a federal court could declare a class arbitration waiver unconscionable.

146. No. 10 Civ. 6950(LBS)(JCF), 2011 WL 2671813, at*3 (S.D.N.Y. July 7, 2011).

147. Id.

148. Id.

149. Id. at *4-5 (quoting In re Am. Express Merchs. Litig. (Amex II), 634 F.3d 187, 199 (2d Cir. 2011)); cf. Karp v. Cigna Healthcare, Inc., No. 11-10361-FDS, 2012 WL 1358652, at*11 (D. Mass. Apr. 18, 2012) (compelling bilateral arbitration of Title VII pattern and practice discrimination claim).

150. No. 10 Civ. 3332(KMW)(MHD), 2012 WL 130420, at *5-7, *9 (S.D.N.Y. Jan. 17, 2012). 
enforce claims of the Fair Labor Standards Act (FLSA). ${ }^{151}$ The plaintiff had filed a putative class action under FLSA, alleging the defendantemployer wrongfully classified her as exempt from the overtime requirements of FLSA. ${ }^{152}$ The court had previously denied the defendant's motion to dismiss based on the class waiver, finding that "[t]he record supports [the plaintiff's] argument that [pursuant to the Agreement] her maximum potential recovery would be too meager to justify the expenses required for the individual prosecution of her claim.”"153 The defendant sought reconsideration of the court's ruling that the class waiver was invalid because it deprived plaintiff of the ability to vindicate her rights, asserting that the new law under Concepcion compelled reversal. ${ }^{154}$ In adhering to the original ruling, Judge Wood emphasized the plaintiff's inability to "vindicate her rights absent a collective action," as opposed to the Concepcions' ability to vindicate their claims under AT\&T's customer-friendly dispute resolution policy. ${ }^{155}$ Judge Wood stated, “[i]n contrast to the facts in Concepcion, [the plaintiff] has demonstrated that she would not be able to obtain representation or vindicate her rights on an individual basis."156 Judge Wood further cited Supreme Court jurisprudence in which the Court had stated "that it may not enforce contractual agreements that would operate 'as a prospective waiver of a party's right to pursue statutory remedies." "157

The Sutherland decision importantly notes the following:

The enforceability of a class action waiver must be determined on a case-by-case basis, considering the totality of the circumstances including, but not limited to, "the fairness of the provisions, the cost to an individual plaintiff of vindicating the claim when compared to the plaintiff's potential recovery, the ability to recover attorneys' fees and other costs and thus obtain legal representation to prosecute the underlying claim.,"158

\footnotetext{
151. Id. at *7.

152. Id. at *1.

153. Id. at *2 (first and third alternations in original) (quoting Sutherland v. Ernst \& Young LLP, 768 F. Supp. 2d 547, 551 (S.D.N.Y. 2011)) (internal quotation marks omitted).

154. Id. at $* 1$.

155. Id. at $* 5$.

156. Id.

157. Id. at *6 (quoting Mitsubishi Motors Corp. v. Soler Chrysler-Plymouth, Inc., 473 U.S. 614, 637 n.19 (1985)).

158. Id. at *4 (quoting In re Am. Express Merchs. Litig. (Amex I), 554 F.3d 300, 321 (2d Cir. 2009), vacated, Am. Express Co. v. Italian Colors Rest., 130 S. Ct. 2401 (2010)); see also In re Am.
} 
Applying these criteria, Judge Wood determined that the plaintiff could not vindicate her statutory rights in an individual arbitration. ${ }^{159}$ Thus, arbitration agreements that alter or preclude parties from enforcement of federal statutory rights may be outside the purview of Concepcion. Yet, the facts of future cases may find vindication of rights possible. Such was the case in D'Antuono v. Service Road Corp., in which the court stayed a FLSA collective action because the plaintiffs had signed arbitration agreements containing class waivers and asserted that the class waiver did not prevent them from vindicating their FLSA rights. ${ }^{160}$ This issue remains unsettled in the wake of Concepcion.

\section{c. National Labor Relations Act}

The National Labor Relations Board (NLRB) relied upon federal labor law in invalidating a class action waiver in In re D.R. Horton, Inc. ${ }^{161}$ In January 2012, the three-member panel ruled that class action waivers in employment agreements violate section 7 of the National Labor Relations Act (NLRA), which guarantees employees the "right to engage in concerted action for mutual aid or protection" 162 and prohibits employers from interfering with those protected rights. ${ }^{163}$ The employer in D.R. Horton required its employees nationwide to sign a "Mutual Arbitration Agreement" (MAA) as a condition of employment with the company. ${ }^{164}$ The MAA required that all company employees agree to forfeit the right to any form of class action claims and that all individual disputes with the company be submitted for binding arbitration. ${ }^{165}$ In 2008, several similarly situated employees sought to initiate class arbitration, alleging the employer violated the NLRA by requiring the MAA as a condition of employment. ${ }^{166}$ The NLRB held that employers

\footnotetext{
Express Merchs. Litig. (Amex II), 634 F.3d 187, 199 (2d Cir. 2011) (finding unenforceable the class action waiver in the arbitration contract). Compare In re Am. Express Merchs. Litig. (Amex III), 667 F.3d 204, 219 (2d Cir. 2012) (ruling that a class action waiver precluding plaintiffs from enforcing their statutory rights was unenforceable), with Jasso v. Money Mart Express, Inc., No. 11CV-5500 YGR, 2012 WL 1309171, at*10 (N.D. Cal. Apr. 13, 2012) (holding that a class action waiver in an employment arbitration agreement does not itself render arbitration unenforceable).

159. Sutherland, $2012 \mathrm{WL} 130420$, at $* 5$.

160. 789 F. Supp. 2d 308, 344 (D. Conn. 2011).

161. 357 N.L.R.B. No. 184, at *16-17 (Jan. 3, 2012).

162. Id. at *1 (citing National Labor Relations Act, 29 U.S.C. § 157 (2006)).

163. Id. at *5 (citing 29 U.S.C. § 158(a)(1)).

164. Id. at $* 1$.

165. Id.

166. Id. at *1-2.
} 
violate section 7 of the NLRA - the right of employees to engage in concerted action for mutual aid or protection-when they require the employee, as a condition of employment, to sign an agreement precluding class action claims - in both judicial and arbitral forums-and requiring all disputes with the employer to be decided in binding arbitration. ${ }^{167}$

\section{LIFE UNDER CONCEPCION}

That the FAA, enacted in 1925, authorizes private parties to eliminate class and representative actions hardly seems plausible. Yet, the Supreme Court's decision in Concepcion suggests just that. The impact of Concepcion is not fully known and certainly did not bring resolution to the question. Just as Concepcion may be the death knell of arbitral class actions, it may also infect other areas of state legislation and governance. The Court's recent action in vacating and remanding another California Supreme Court decision in Sonic-Calabasas A, Inc. v. Moreno, calls into question whether an arbitration agreement can preclude an employee from pursuing rights under the state labor code, which permits a hearing before the California Labor Commission. ${ }^{168}$ The California Supreme Court in Moreno initially held that the employee could pursue his wage claim under the state administrative proceeding as a prerequisite to arbitration. ${ }^{169}$ The U.S. Supreme Court remanded the case back to the California Supreme Court to consider, in light of Concepcion, whether the state administrative wage proceedings are inconsistent with the FAA, ${ }^{170}$ which suggests that the FAA could potentially displace state administrative options. ${ }^{171}$ The ripple effects of Concepcion and bans on class proceedings are not fully known. ${ }^{172}$

167. Id. at *4-5; see also Philip M. Berkowitz, Developments in Arbitration of Employment Claims, N.Y. L.J., Jan. 12, 2012, http://www.newyorklawjournal.com/PubArticleNY.jsp?id=120253 7831101\&slreturn=1.

168. 132 S. Ct. 496 (2011), vacating and remanding 247 P.3d 130 (Cal. 2011).

169. 247 P.3d at $150-52$.

170. 132 S. Ct. at 496.

171. See, e.g., Preston v. Ferrer, 128 S. Ct. 978, 987 (2008) (holding that "[w]hen parties agree to arbitrate all questions arising under a contract, the FAA supersedes state laws lodging primary jurisdiction in another forum, whether judicial or administrative").

172. Courts could be potentially eliminated from the arbitration process altogether, other than at the judicial review stage, by a delegation provision. See Rent-A-Ctr., W., Inc. v. Jackson, 130 S. Ct. 2772, 2777-78, 2781 (2010) (ruling 5-4 that where an arbitration provision delegates gateway questions concerning the validity and enforceability of the arbitration agreement to arbitrators, unconscionability challenges must be directed to the delegation provision alone, thus ultimately 


\section{A. Federal Legislative Action}

As the Supreme Court's jurisprudence enables broad enforcement of private arbitration contracts, including those that can deny parties rights to collective action and usurp states from administrative action, Congress is increasingly responding to calls for protection against mandatory arbitration in certain sectors. ${ }^{173}$ Legislation seeking to limit or invalidate the FAA's application in various areas has been the subject of much congressional attention.

Legislation for a proposed Arbitration Fairness Act has been introduced almost annually over the past five years. In its current version, the proposed Arbitration Fairness Act of 2011 would invalidate pre-dispute arbitration contracts in consumer, employment, and civil rights actions. ${ }^{174}$ The Arbitration Fairness Act proposal has generated significant controversy among ardent supporters and opponents, and it continues to face obstacles in garnering enough support to be enacted. ${ }^{175}$

Instead, Congress has taken an industry-specific approach in legislating limits on pre-dispute arbitration. In the Military Lending Act of 2007, Congress added federal protection for American military personnel against certain types of predatory consumer lending and invalidated mandatory arbitration or waiver of rights in consumer credit contracts with military personnel. ${ }^{176}$ Farmers were given the choice to

passing on the broader issue because the challenge raised was to the contract as a whole); $c f$. Hall Street Assocs., LLC v. Mattel, Inc., 552 U.S. 576, 586-89 (2008) (holding that parties cannot by private contract agree to expand the scope of judicial review under the FAA).

173. See generally Amy Schmitz, Arbitration Ambush in a Policy Polemic, 3 Penn ST. Y.B. ON ARB. \& MEDIATION 52 (2011) (discussing congressional responses to Supreme Court decisions).

174. Arbitration Fairness Act of 2011, H.R. 1873, 112th Cong. (1st Sess. 2011); Arbitration Fairness Act of 2011, S. 987, 112th Cong. (1st Sess. 2011).

175. See, e.g., Peter B. Rutledge, Who Can Be Against Fairness? The Case Against the Arbitration Fairness Act, 98 CARDOZO J. CONFLICT RESOL. 267 (2008) (laying out the author's case against the arbitration act and explaining why post-dispute arbitration is not a viable alternative to the current use of pre-dispute arbitration clauses); Weston, supra note 30, at 398 (noting that the legislative change proposed in Weston's note and in the Arbitration Fairness Act of 2007 would "radically change... corporate uses of arbitration provisions in contracts with employees, consumers, and franchisees" and that "the supporters of arbitration status quo may be more mobilized to convince federal lawmakers that the FAA is alright as is").

176. See 10 U.S.C. § 987(e)(3) (2006) ("It shall be unlawful for any creditor to extend consumer credit to a covered member or a dependent of such a member with respect to which ... the creditor requires the borrower to submit to arbitration or imposes onerous legal notice provisions in the case of a dispute.”); § 987(f)(4) (“Notwithstanding section 2 of title 9, or any other Federal or State law, rule, or regulation, no agreement to arbitrate any dispute involving the extension of consumer credit shall be enforceable against any covered member or dependent of such a member, or any person who was a covered member or dependent of that member when the agreement was made.”). 
opt out of arbitration in contracts involving livestock or poultry under the Food, Conservation and Energy Act of 2008. ${ }^{177}$ This protection is similar to that accorded automobile dealers in the Motor Vehicle Franchise Act, which requires post-dispute consent to arbitration by all parties. ${ }^{178}$ Lastly, in 2009, the Fairness in Nursing Home Arbitration Act attempted to restrict mandatory arbitration in nursing home contracts with residents. ${ }^{179}$

Congress is also gradually limiting pre-dispute arbitration of statutory disputes in employment. In response to the concerns raised in Jones v. Halliburton, Co., which involved sexual assault claims arising in Iraq by an employee against a military contractor, ${ }^{180}$ Congress passed the Department of Defense Appropriations Act of 2010, which bars many defense contractors and subcontractors from using pre-dispute arbitration agreements as a condition of employment. ${ }^{181}$ Similarly, the Dodd-Frank Wall Street Reform and Consumer Protection Act prohibits pre-dispute agreements to arbitrate certain whistleblower claims brought against public companies and many financial services institutions. ${ }^{182}$

\section{B. Proposed Federal Legislative Action to Address Class Waivers}

After Concepcion, the state of class arbitrations and the future of class actions are in a flux. It is appropriate and necessary for Congress to respond by simply amending the FAA to restrict class waivers. The congressional intention to restrict arbitration must be explicit, as the Court is not inclined to imply a conflict between a federal statutory right to sue and the FAA even in an adhesive pre-dispute arbitration

177. See 7 U.S.C. § 197c(e) (2006 \& Supp. 2009) (stating that "[a]ny action by or on behalf of a packer, swine contractor, or live poultry dealer ... that has the intent or effect of limiting the ability" of a poultry grower to opt out of the arbitration provision is an unlawful practice under the Act).

178. See 15 U.S.C. § 1226(a)(2) (2006) ("Notwithstanding any other provision of law, whenever a motor vehicle franchise contract provides for the use of arbitration to resolve a controversy arising out of or relating to such contract, arbitration may be used to settle such controversy only if after such controversy arises all parties to such controversy consent in writing to use arbitration to settle such controversy.").

179. Fairness in Nursing Home Arbitration Act of 2009, H.R. 1237, 111th Cong. (1st Sess. 2009); Fairness in Nursing Home Arbitration Act of 2009, S. 512, 111th Cong. (1st Sess. 2009).

180. 583 F.3d 228, 231 (5th Cir. 2009).

181. Department of Defense Appropriations Act of 2010, Pub. L. No. 111-118, 123 Stat. 3409 (2009), amended by Franken Amendment, S. Amend. 2588 (2009).

182. Dodd-Frank Wall Street Reform \& Consumer Protection Act, Pub. L. No. 111-203, 124 Stat. 1376 (2010). 
agreement. ${ }^{183}$ In CompuCredit Corp. v. Greenwood, the Supreme Court addressed "whether the Credit Repair Organizations Act (CROA) precludes enforcement of an arbitration agreement in a lawsuit alleging violations of that Act." "184 CROA provides a right to sue for violations under the consumer protection statute. ${ }^{185}$ The plaintiffs in CompuCredit sought class status and voidance of the class arbitration waiver, contending that CROA's right to sue disallowed contractual waivers on the right for CROA violations. ${ }^{186}$ The Court did not view the arbitration requirement as conflicting with CROA because the statute did not require a judicial forum, and the right to sue could be effectuated through arbitration. ${ }^{187}$

\section{CONCLUSION}

Concepcion, based on a dated notion of arbitration, improperly guts the FAA savings clause and violates the reserved role under the FAA for states to hold arbitration contracts to the standards required for all contracts. Certainly, the FAA was not intended to shield wrongdoers from liability. That risk, however, is present where class action waivers have the effect of allowing small but widespread illegality claims to go unheard. Perhaps Concepcion will ring louder the calls for legislative reform of the FAA to address concerns of mandatory arbitration. Some rights can only be vindicated through collective action. The public function served by collective action through procedural joinder is too important to be eliminated by the strike of a pen. Consent to arbitration and a meaningful opportunity to vindicate rights need not conflict.

\footnotetext{
183. See supra Part IV.

184. 132 S. Ct. 665, 668 (2012) (citation omitted).

185. See 15 U.S.C. § 1679 c(a) (2006) (requiring credit repair organizations to provide consumers with a statement detailing their rights, including a right to sue).

186. $132 \mathrm{~S}$. Ct. at $668-69$.

187. Id. at 672-73 ("Because the CROA is silent on whether claims under the Act can proceed in an arbitrable forum, the [FAA] requires the arbitration agreement to be enforced according to its terms.”).
} 